POLIIICAL ECONOMY RESEARCH INSIITUTE

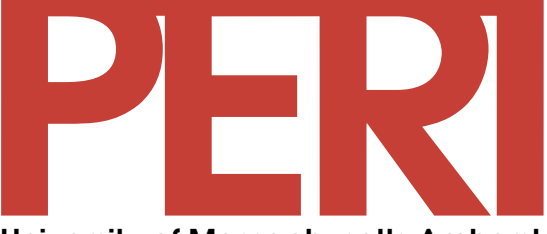

University of Massachusetts Amherst

\title{
Globalization and the Transition to Egalitarian Development
}

\author{
Robert Pollin
}

2002

10th floor Thompson Hall University of Massachusetts Amherst, MA, 01003-7510 Telephone: (413) 545-6355 Facsimile: (413) 545-2921

Email:peri@econs.umass.edu Website:

http://www.umass.edu/peri/

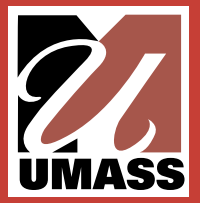




\title{
Preliminary Draft: Comments are Welcome
}

\section{Globalization and the Transition to Egalitarian Development}

\author{
By \\ Robert Pollin \\ Department of Economics and \\ Political Economy Research Institute (PERI) \\ University of Massachusetts-Amherst \\ Amherst, MA 01003-7510 \\ pollin@econs.umass.edu
}

September 2002

Prepared for Festschrift volume in honor of Prof. Keith Griffin, edited by Steven Cullenberg and Prasanta Pattanaik.

I wish to thank James Heintz for his extremely able assistance and Jerry Epstein for the long and detailed discussions we have had on the topic of this paper and for his careful reading of the paper itself. 
Keith Griffin is one of the giants of economics in our time. His writings on egalitarian development are of course prodigious and highly influential. But what sets him apart from even other leading thinkers in this field is his focus not simply on what should be done to advance an egalitarian development path, but also the specific means through which a more equal society that is also sustainable might actually be achieved. The Transition to Egalitarian Development (1981) was the title of just one of his many works reflecting this set of concerns and approach to research. This should not be surprising, since many of Griffin's most important works emerged out of specific projects in which he was advising governments throughout the world on precisely the question of how to advance a workable transition toward egalitarian development.

I have been absorbing the strong force field emanating from Keith Griffin since we first became colleagues at the University of California-Riverside in 1988. As a political economist of the left, I always assumed part of my job description was to think about what might be realistic strategies for moving capitalist societies from where they are today to where we would like them to be in the not-too-distant-future. I confess to having at times felt frustration by the relative lack of attention among like-minded colleagues to this issue. Keith Griffin ponders this and related matters - the 'how to get from here to there' questions - every day he walks into his office. You can't work in the same building as Keith and miss this central fact of his professional existence.

Providing coherent answers to such questions has become decidedly more challenging during our contemporary historical epoch, known variously as 'the era of globalization,' 'the era of neoliberalism,' or some combination of the two. Keith Griffin, characteristically, has accepted this challenge. Just since the time when we became colleagues in 1988, Keith has led advising missions to Bolivia, Mongolia, Uzbekistan, Vietnam, and Kazakstan, and has published substantial research works drawing from these engagements. Advising national governments in our current era cannot be done without spending lots of time contemplating the effects of globalization. Having been with Keith in Bolivia, I saw first hand that even progressive governments - or maybe especially progressive governments - have become disoriented in their approach to policy due to what they perceive as the constraints on them imposed by globalization. Griffin has also regularly opened a wider lens in his observations and analysis on globalization, combining his first-hand knowledge of how economies actually operate with a sweeping array of economic, social, historical and cultural insights. ${ }^{1}$

In this essay, I attempt to synthesize these various features of the Griffin approach to doing economics to excavate the question of globalization. Specifically, within the context of our contemporary historical epoch, I wish to explore what I take to be the basic Griffin questionhow can we advance a transition to egalitarian development within the context of globalization? Considering this question in its full scope entails, by definition, examining the global economy as a whole. Obviously, one cannot hope to touch on even a small fraction of the significant issues flowing from this topic within a single essay, and I do not pretend to try. In fact, while the scope of this essay is wide, my ambition remains relatively modest - to generate some usable perspectives, leading to concrete policy ideas, that might be more difficult to perceive through approaches that are more narrowly focused.

We begin with what I take to be the single most important fact about the contemporary pattern of global economic integration. This is that it is being guided by a predominant commitment to neoliberal economic policies throughout the world. Such policies include more openness to trade and foreign direct investment, fewer government regulations of financial markets and institutions and other sectors, and a substantially reduced role for macroeconomic

\footnotetext{
${ }^{1}$ As a sampling of Griffin's more general writings on globalization, see (1994, 1997a, 1997b, 1999a, 199b)
} 
policy management. How one assesses the implications of this process of neoliberal globalization depends on the analytic perspective from which one approaches the question. The majority of mainstream economists regard neoliberal globalization as a fundamentally benign process. Of course, such a view follows logically from a broader perspective that holds that that the operation of free markets in a capitalist economy generates efficiency, a stable macroeconomic environment and as close an approximation to a fair distribution of income as is likely to be attained. But from the left dissident traditions in economics, one would begin from a premise that neoliberal globalization is likely to engender systemic unemployment, increasing disparities in income and wealth, and greater macroeconomic instability, even while it may still promote market competition and greater efficiency in some areas.

The paper proceeds by first discussing the term "globalization" itself. Moving onward, the paper is structured around three overarching problem which have emerged in this era of neoliberal globalization. I term these "the Marx problem," "the Keynes problem," and "the Polanyi problem." The Marx problem refers to the expansion of what Marx termed the "reserve army of labor," which has resulted from a range of structural changes and policy responses in the era of globalization. The Keynes problem is that highly liquid financial markets, such as those that have emerged on a global scale in our current era, are prone to bouts of speculation and instability. Financial instability, in turn, is frequently transmitted into the real economy, creating serve cyclical volatility in incomes and employment. The Polanyi problem concerns the ability of non-market forces to engender norms of social solidarity that can serve as effective counterweights to the competitive imperatives of a free-market economy.

In structuring the paper in this way, I hope to show how the array of problems due to neoliberal globalization are interrelated. This simple point can become obscured when one separately considers, for example, trade policy, foreign direct investment, and financial markets; or, for that matter, the specific practices of the International Monetary Fund, World Bank, or World Trade Organization. I will argue that the fundamental problems with, for example, liberalizing trade do not stem from the expansion of trade itself. They rather result from the fact that, in the current policy environment, trade opening has led to growth in the reserve army of labor, and thus a shift in bargaining power that favors employers over workers. In addition, for many developing economies, the revenues generated by tariffs had been a significant fraction of total government revenues. In these cases, trade opening has therefore effectively meant cuts in government spending on social services, i.e. exacerbating a country's Polanyi problem. And still again: proponents of neoliberal globalization hold that opening financial markets creates benefits parallel to those of trade expansion. I would rather argue that effective regulations of financial flows - i.e. addressing the Keynes problem — are a precondition for attaining the possible benefits from trade opening.

\section{What is Globalization?}

The answer is not obvious. The major technical innovations in communications and transportation technologies have reduced the transaction costs of maintaining effective economic links on a global scale. Moreover, the collapse of the Soviet system eliminated this challenge to capitalist hegemony, even though the governments professing to Communism had long since abandoned any serious claim to a democratic, egalitarian alternative to free market capitalism. The result, in any case, is that huge areas of the world economy were now opened to capitalism to a degree unprecedented in generations.

The basic perception that pervades contemporary discussions about globalization is that the relationship between economic activity and nation states is dramatically changing. This 
means, first, that the extent of economic interactions between people in different countries is simply growing, at an ever-accelerating rate: that there is increasingly more trade, more foreign exchange transactions, more foreign direct investment, and more people migrating. But in addition to the increase in international economic interactions, it is also widely held that something more fundamental is occurring: that the quantitative increase in interactions is producing a qualitative change in the way nation-states operate within any given country's economy. In particular, most discussions of globalization hold that the power of nation-states to influence economic activity is eroding as economies become more integrated, while the power of businesses and market forces is correspondingly rising. These widely-held perceptions enable us to provide an working definition to the term "globalization." It refers to an accelerating rate and/or higher level of economic interaction between people of different countries, leading to qualitative shifts in the relationships between nation-states, national economies, social classes, and markets.

Based on this working definition, we then need to ask what is unique about the degree of economic integration in the contemporary period that sets it apart from previous historical epochs. Starting with a seminal paper by the late David Gordon (1988), a substantial literature has developed in recent years that argues that the contemporary pattern of globalization does not represent a significant break from patterns that operated through most of the $20^{\text {th }}$ century ${ }^{2}$.

Some of the key evidence in support of this view is as follows:

1. Relative to GDP, the amount and rate of increase in world trade has not changed significantly relative to the early part of the $20^{\text {th }}$ century, i.e. the period just before World War I.

2. The extent of overall foreign direct investment has also not increased significantly relative to previous historical periods.

3. The overwhelming share of both trade and foreign direct investment is between OECD countries at similar levels of development, not between countries of the wealthier "North" and the poor "South."

4. Net financial flows between countries, as measured, for example, by the percentage of total current account surpluses or deficits relative to GDP, are also currently at levels roughly equivalent to those during the 1920s, and are lower than those at the turn of the century.

Based on evidence such as this, Gordon and other authors in this stream of thought contend that the contemporary extent of global integration is not historically unique-which is to say, no inevitable qualitative break has occurred in our contemporary period in the relationship between national economies. From this, they also argue that there is no necessary reason that governments have become increasingly committed to the prevailing neoliberal policy regime.

The general empirical findings advanced in behalf of this perspective are beyond dispute, and the researchers who have developed this evidence have certainly clarified the issues at hand. But it does not follow that such evidence, by itself, provides an adequate empirical understanding of the nature of globalization in our current era, much less about policy constraints governments face in this current period.

In fact, crucial new patterns in global economic activity have emerged in the contemporary period. Two, in particular, stand out: the rise in manufacturing capacity in less

\footnotetext{
${ }^{2}$ See also Zevin (1992) and Sutcliffe and Glyn (1999).
} 
developed economies; and the exponential growth in gross financial market trading across borders and in foreign exchange markets. These two developments could not have occurred without the advances of our time in communications and transportation technology. But to understand their economic impact, we must consider them within the context of the Marx, Keynes, and Polanyi problems, and the ascendancy of neoliberal economic policy-the task to which we now turn.

\section{The Marx Problem}

Levels of employment and compensation - the most basic determinants of well-being for the majority of the world's population - are established through various processes of bargaining between workers and employers. Marx argued that, in general, workers have less bargaining power than employers in labor markets because they do not own their own means of production. But Marx also stressed that workers' bargaining power diminishes further when unemployment and underemployment are high, since that means that employed workers can be readily replaced by the reserve army outside the factory gates. Some variation of Marx's basic observation has been restated innumerable times in the professional literature, including recent work on NAIRU and the so-called "wage curve," . Understanding this relationship is central to grasping the broad effects of neoliberal globalization on working people in both the global North and South.

\section{Workers in the North}

The era of globalization has been characterized by a sharp decline in the economic fortunes of the majority of lower-paid workers in the leading industrialized countries. The trend is manifested through declining wages and growing inequality in the United States, and persistently high unemployment in Europe. ${ }^{4}$ But the fact of rising earnings inequality in the United States and persistently high unemployment in Europe does not, in itself, provide any explanation as to the causes of these trends. What are the main causal relationships? We consider this question first in terms of the global North, then the South.

\section{Alternative Perspectives on Northern Wage Inequality and Unemployment}

Skill-biased technical change. The prevailing explanation among economists does not rely at all on incorporating the effects of globalization. Rather, what has been termed a "skillbiased technological change" is seen by the majority of observers as the primary explanation for the observed trends in both the U.S. and Europe. ${ }^{5}$ According to this view, the rapid integration of computer technology into all areas of economic life has created an increased demand for workers who are capable of operating effectively with computers. Demand has correspondingly fallen for workers without computer skills. This relative shift in demand for the computer-skilled versus the unskilled has, in turn, increased the relative wage differential between those with and without computer skills.

According to this perspective, the impact of skill-biased technical change has differed in the U.S. and Europe because labor markets are much more flexible in the United States than in

\footnotetext{
${ }^{3}$ See, for example, Blanchflower and Oswald (1995), Layard, Nickell and Jackman (1991), and Pollin (1998a).

${ }^{4}$ See Mishel, Bernstein and Schmitt (2000) and Glyn (1995) for reviews of some basic evidence on these trends.

${ }^{5}$ Some major references include OECD (1994a, 1994b), Berman, Machin and Bound (1996), and

Krugman (1994).
} 
Europe. As such, in the U.S., the primary impact of skill-biased technical change has been to increase wage inequality between the skilled and unskilled. In Europe, the primary effect has been to increase unemployment among the unskilled, since European labor market regulations will not permit wages of the unskilled to fall to the point where businesses are willing to hire them. Overall, a large number of economists believe that the skill-biased technological change phenomenon provides what Blank (1997) terms a "unified theory," capable of explaining both U.S. wage inequality and European unemployment.

But despite having achieved broad assent among economists, this unified theory has been shown to rest on extremely fragile empirical foundations. For example, in an important series of papers, David Howell and colleagues (e.g. 1998, 1999a, 199b) "find no direct evidence of an historically distinctive, much less accelerating, shift in the skill mix of employment since the early 1980s in the U.S. or in most other major OECD countries $(1998$, p. 3)." Indeed, among other things, they find that the observed change in skill mix is far greater from the early 1970s to the early 1980s, that is, in the period immediately prior to the onset of widespread computerization. Card and DiNardo (2002) have recently affirmed Howell's basic conclusions.

Trade with Low-Wage Economies. The literature does explore alternatives to the unified theory. Prominent among these are efforts to explicitly consider the role of globalization in generating the observed wage and employment trends. ${ }^{6}$ However, in developing this alternative approach, measuring the impact of globalization is almost always based on a narrow definition of the term - that is, statistics of manufacturing trade penetration from low-wage economies are generally taken to themselves fully represent the effects of globalization on workers in the U.S. and Europe. Again, what is crucial about globalization in our contemporary epoch is not simply that integration is proceeding, but that a neoliberal policy agenda sets the terms in which integration occurs. Therefore the effects of increased manufacturing capacity from the South need to be examined within this broader analytic perspective.

Expansion of Reserve Army and Institutional Shifts. In terms of the contemporary global setting, the dynamics of the reserve army effect in high-wage economies changes when firms operating in low-wage economies can produce export-competitive manufactured products. In this situation, the potential size of the reserve army necessarily expands to also include both the unemployed and, even more to the point, employed but low-paid workers in the developing economies. As such, the capitalists in the advanced economies have gained an additional bargaining advantage in wage-setting negotiations. This is because firms can now credibly claim that their own relatively high labor costs will threaten their export markets and increase import competition from low-wage competitors. In addition, the firms in high-wage economies whose operations are not tied to a specific location can credibly threaten to move to low-wage economies if costs in their current locations appear too high. The crucial issue here is not that firms actually leave their existing high-wage location but that they can brandish a credible threat to exit. ${ }^{7}$

Moreover, what makes such threats credible is not the rise of low-wage countries manufacturing capacity alone. Rather, it is that, given the rise in export competitiveness among low-wage countries, the governments of the advanced economies have not acted to counter the increased bargaining power accruing to capitalists. Quite the contrary-by pursuing the deregulation of labor markets and abandoning employment-targeted macroeconomic policies, the

\footnotetext{
${ }^{6}$ Cline (1997) provides an excellent survey of this literature.

${ }^{7}$ This same point is developed, if from a different analytic framework, in Rodrik (1997).
} 
governments of the advanced economies have only strengthened further the relative bargaining power of capital over labor.

Bronfenbrenner (1996) has conducted the most directly relevant study of how threat effects per se have influenced labor negotiations. She reports the results of a survey between 1993-95, which showed that 50 percent of all firms and 65 percent of manufacturing firms that were targets of union organizing campaigns threatened to close their shops and relocate if the workers voted to unionize. Though only 12 percent of those firms that ended up unionized did then carry through on their threat to relocate, workers nevertheless found the threats credible. In particular, in cases where firms did make threats to shutdown or relocate, unions lost a significantly larger percentage of elections. In related research, Fortin and Lemieux (1997) tested the extent to which "quantifiable measures of institutional forces" can explain the rise of U.S. earnings inequality. They conclude that about one-third of the growth of inequality in the 1980s can be attributed to changes in three such forces: the real value of the minimum wage, the unionization rate, and economic deregulation. They also make clear that their model did not attempt to measure the effects of "cultural or social norms that may play an important role in wage determination, but are difficult to quantify."

\section{Workers in the South}

If one follows the factor price equalization theory, it should not be surprising that the well-being of Northern workers should fall as neoliberal globalization proceeds. That is, wages should go down in rich countries while rising in poor countries as rich and poor countries become more closely integrated. ${ }^{8}$

Global integration should therefore be offering a decided benefit to Southern workers - that their wages would rise toward the level of Northern workers. However, to reach this conclusion about upward wage tendencies in the South, the factor-priceequalization model makes two crucial assumptions: that both the rich and poor countries operate at full employment and that they utilize identical production technologies. In reality, neither of these assumptions corresponds to reality. Rather, most developing countries have abundant numbers of people - perhaps the majority of the adult labor force - who are underemployed in some form or another. In terms of technologies, both in manufacturing and agriculture, most developing economies have employed significantly less advanced production methods than those in rich countries during the period in which they have opened their economies.

Relaxing these assumptions of the factor price equalization model means that the impact of increased integration in developing countries becomes contingent on the labor market and technological conditions in these countries as they interact with the ascendant neoliberal policy regime. ${ }^{9}$

\footnotetext{
${ }^{8}$ We recognize that a wide range of economists do not consider this a realistic model (e.g. Bhagwati and Dehejia 1994). But it is still useful because - as with the Arrow-Debreau model of general equilibrium - it enables one to pursue a more systematic analysis through examining the ways in which the assumptions of the model need to be relaxed.

${ }^{9}$ Larudee (1998) presents an important demonstration of this point as regarding Mexico and the United States.
} 
Migration from Agriculture.

Beginning with the early literature on development economics in the 1950s, economists such as Nurske (1953) and Lewis (1955) argued that less developed economies operate with large supplies of "surplus labor" or "disguised unemployment" in the rural sectors. Nurske and Lewis held that these conditions offered an opportunity for less developed economies-i.e. that workers could be transferred from agricultural to non-agricultural employment without having to sacrifice agricultural output. Rather, the movement of labor into non-agricultural activities would be a key element enabling non-agricultural output to rise.

Nonagricultural output has generally risen dramatically in developing countries since World War II. But the migration out of agriculture then created a new problem: that the supply of labor from agriculture was exceeding the demand, initially in urban areas, then increasingly in rural nonfarm sectors as well. This has produced a long-run source of downward pressure on wages in developing countries.

This tendency has accelerated under conditions of neoliberal globalization, resulting from the interaction of several factors. First, the reduction or elimination of tariffs on agricultural products has enabled cheap imported grains and other agricultural products to capture an increasing share of the developing countries' markets. Agricultural producers in developing countries have also shifted their own target markets, as the most lucrative activities have become exporting fresh fruits and vegetables as well as wood and wood products to North American, European and Japanese markets. This development favors large-scale, capital-intensive agriculture. Finally, neoliberal policies have brought reductions, if not outright elimination, of agricultural subsidies to smallholders. ${ }^{10}$

\section{Growth of Rural Non-Farm Labor}

For the past 25 years, the most important growing tendency among smallholders in the third world has been to join the rural non-farm labor market rather than entering the urban labor pool. According to studies by Reardon and various co-authors $(1998,2001)$, rural non-farm labor employment in the 1990s accounted for between $35-45$ percent of rural incomes in Latin America, Asia and Africa, exceeding incomes from self-employment, farm wages, and remittances from migrants. Reardon et al find that there is wide variation in the types of jobs falling within this category and the corresponding wages paid for them. They include traditional activities such as crop transport, grain milling or production of so-called "Z-goods" such as baskets or mats. They also include domestic employment in rising tourist areas or rural bedroom communities and production of modern non-farm goods, using modern production and financing methods and higher-skilled labor.

Given this wide range of job types, the largest variables affecting wages are workers' educational attainment level and the level of rural infrastructure. Because neoliberal policies have entailed cuts in public-sector expenditures, including in education and infrastructure, these cuts in turn hold back the growth of better-paying non-farm rural jobs. ${ }^{11}$

\footnotetext{
${ }^{10}$ These trends are described in various essays in Bryceson, Kay and Mooij (2000)

${ }^{11}$ At the same time, slowing the development of rural infrastructures does also, ironically, create a countertendency, in that it slows the rate at which imports and domestic products from urban areas achieve a dominant position in rural areas.
} 


\section{Labor Market Effects of Export-Led Manufacturing}

Following the Heckscher-Ohlin framework, one would expect labor-intensive jobs to be transferred from the high-wage to low-wage countries as trade expands. And while the share of manufacturing exports from developing countries has risen dramatically, this has not generally translated into more manufacturing employment in developing countries.

Thus, according to the WTO, the share of developing economies in world manufacturing goods exports rose from 11.2 percent in 1980 to 24.8 percent in 1999. However, this growth in manufacturing exports has been concentrated in 13 developing countries-Argentina, Brazil, China, Hong Kong China, India, Indonesia, Malaysia, Mexico, the Philippines, Singapore, South Korea, Taiwan China and Thailand. ${ }^{12}$

But even among these countries, employment in manufacturing has not generally grown. Using aggregated national data from UNIDO, for example, we observe that growth in manufacturing employment between 1985-98 averaged 9.0 percent for Malaysia, 5.8 percent for China, and 4.4 percent for Chile, but -2.2 percent for Brazil, -2.1 percent for Argentina, - 0.5 percent for Mexico and -0.3 percent for Taiwan.

Ghosh (2000) has argued that three factors explain the lack of manufacturing job growth in developing countries. ${ }^{13}$ The first is the fallacy of composition in export expansion. That is, while an export-led growth strategy may be perfectly viable for some subset of developing economies, when all developing countries attempt the same strategy, increasing competition for the same export markets, many countries are likely to fail. This point had long been recognized in considering countries whose exports were mostly primary products. However, many proponents of export-led growth held that opportunities for success would increase substantially when developing countries were able to diversify their export offerings to include manufactured products. But experience over the past 20 years has contradicted this view: it now appears true that competition does indeed limit the number of countries that can succeed by emphasizing exports as their primary growth engine.

The second factor is a substitution effect within the developing countries' own domestic markets. Many of the countries that have been working to develop export-competitive manufacturing sectors already had large-scale manufacturing sectors in operation, though these earlier-vintage manufacturing sectors concentrated on producing for their domestic markets. This is most clearly the case among the large Latin American economies-Mexico, Brazil and Argentina-whose industrialization strategy through the 1970s was built around an importsubstitution model. The liberalization of trade policies has therefore led to two results in these countries: an expansion of their exporting capacity, but a corresponding increase in the penetration of their domestic markets by imports.

This substitution effect also creates the conditions for a third, productivity effect, as manufacturing shifts from focusing on domestic markets to exports. For developing countries to become successful as exporters that they compete on the basis of productivity as well as on wage rates. To a large extent, this entails appropriating more capital-intensive, higher-productivity, technologies, even if not always the cutting-edge production methods utilized in more advanced economies. Thus, the shift from targeting manufacturing production from domestic markets to

\footnotetext{
12 The figures from this and the next paragraph are reported in Ghosh (2000).

${ }^{13}$ Alarcon and Zepeda (1998) present evidence focused on the Mexican manufacturing industry which supports these same points.
} 
exports has generated a tendency for labor-shedding among manufacturers in developing countries.

Workers in developing countries employed in the successful exporting firms do generally enjoy a wage premium over the domestic market average, corresponding to the higher rates of both sales and productivity growth at these exporting firms. But even this narrowly-targeted premium can be less than would otherwise be the case, given the large and growing pool of underemployed workers both within and outside the formal manufacturing sector. This persistence of underemployed and informal sector workers in developing countries continues to exert downward pressure on overall wage levels in these countries.

\section{The Keynes Problem}

\section{Systemic Instability and the Case for Financial Regulation}

The Keynes problem flows from a fundamental fact about the nature of capitalist economies: that the investment process - the basic activity which is a proximate determinate of an economy's level of income, employment and productivity growth - is unstable because it operates on the basis of uncertainty. As Keynes (1936) famously put it, "we simply do not know" how profitable a prospective investment project will be. A primary purpose of financial markets is to ameliorate problems due to uncertainty through increasing the liquidity of investments. When financial instruments are freely traded in relatively thick markets, illiquid investments in plant and equipment can be transformed into claims that are convertible into cash or other liquid assets as quickly as the institutional and technological structures permit.

However, enhancing the liquidity of assets also tends to create serious problems for the stability of capitalist economies. An initial analysis of these sources of instability was presented forcefully in Keynes's General Theory. But this critical literature has also developed widely since Keynes. One important contribution has been that of Robert Schiller (e.g. 2000), who emphasizes the role of investor psychology, independent of individual firm fundamentals, as a major determinant of stock market prices. Related to Schiller's critique are arguments about the centrality of asymmetric information in financial markets, and specifically the influence exerted by ill-informed "noise traders." For example, Shleifer's (2000) presentation of the "behavioral finance" perspective models financial markets as containing two kinds of traders, fundamental traders and noise traders. But noise traders are not competed out of the market by the fundamental traders in this perspective. This is because arbitrage is risky, costly, and therefore limited. For example, when stock prices are inflated relative to fundamentals, arbitraurs who choose to sell short face potential losses from prices moving still higher under the influence of noise traders - that is, their short-selling will not necessarily drive prices down to fundamentals. Thus, the actions of noise traders are not merely ephemeral to market activity, but rather exert a sustained influence on price formation.

But a deeper point about Keynesian uncertainly also emerges from this perspective. If noise traders persistently and unpredictably move markets away from fundamentals, it no longer becomes logical for even well-informed traders and professionals to try to trade on the basis of fundamental information. It rather follows that professional traders should proceed as Keynes argued, to trade by trying to outguess market sentiment, moving ahead of the herd by "anticipating what average opinion thinks average opinion to be," $\left(1936\right.$, p. 156). ${ }^{14}$

\footnotetext{
${ }^{14}$ See Crotty (1994) for a contemporary perspective on this question.
} 
Systems of Financial Regulation.

Overall then, according to these critical perspectives, thick but unregulated financial markets operate with substantial degrees of inefficiently and irrationally. The general logic of this Keynesian perspective was the analytic foundation on which the post Depression and World War systems of financial regulations were constructed. These regulations included the Bretton Woods system of fixed exchange rates and related capital control measures, implemented at the level of domestic economies, to control international capital flows and speculative currency markets. ${ }^{15}$ The Glass-Steagall system of domestic financial regulations was established in the United States. The main purpose of these regulations was to create barriers between various segments of the overall financial market, to limit the portfolio options for each market segment, and to regulate interest rates. ${ }^{16}$ Even more extensive systems of domestic financial regulations operated in most European economies and Japan. Government regulations played a major role in determining the allocation of credit, and thus the level and composition of investment, as government regulators operated in close association with banks and nonfinancial businesses. The capital markets played a much more limited role in these economies in terms of mobilizing funds, allocating credit and influencing investment decisions. ${ }^{17}$

The Demise of Financial Regulations.

These regulatory systems were strongly criticized virtually from the outset by free market proponents. But the emergence of a persistent inflationary environment was more important to the demise of financial regulations than any purely academic critique. Among other difficulties created by inflation were sustaining appropriate exchange rates, managing interest rate ceilings, and limiting asset acquisition options for separate segments of financial markets. But within a neoliberal analytic framework, these problems generated by inflation were seen as evidence in behalf of opening markets and minimizing regulations, not the basis for reforming the regulatory environment. This was the basis on which, from the 1970s onward, financial markets globally have been increasingly deregulated. ${ }^{18}$

\section{Dramatic Shifts in International Financial Flows.}

Since the demise of Bretton Woods and the emergence of deregulated financial markets, there has been an enormous increase in gross flows, i.e. the total amount of international lending as well as secondary market trading in stock, bond, foreign exchange, and derivative markets. We present some representative data on these trends in Table 1.

\section{TABLE 1 BELONGS HERE}

To begin with, panel 1A shows the total amount of funds raised on international financial markets relative to world exports from 1950-97. For 1950, this figure was only 0.5 percent. It rises to 1.8 percent by 1970, still prior to the collapse of Bretton Woods. But post-Bretton Woods the ratio rises rapidly in the mid-1970s through the mid-1980s. By 1985, the ratio is 13.5 percent-

\footnotetext{
${ }^{15}$ Panic (1995) provides a useful brief overview of the initial design of the Bretton Woods system.

${ }^{16}$ Essays in Dymski, Epstein and Pollin (1993) describe the structure and evolution of the Glass Steagall system.

${ }^{17}$ These financial structures are described in Zysman (1983), Pollin (1995), and Grabel (1997).

${ }^{18}$ See Schaberg (2000) for institutional and econometric discussions of the decline of financial regulatory systems.
} 
-a six-fold increase over 1970. By 1997, the figure we report is up to 23.7 percent, showing a continuing dramatic rise. ${ }^{19}$

Panel 1B then shows more detailed breakdown of foreign transaction between 1980-98 in bonds and equities as a percentage of GDP for six OECD countries, including here both secondary trading as well as primary issues. In all six cases, the jump in cross border flows from 1980 has been spectacular--e.g. for the United States, the ratio of cross border transactions/GDP rose from 9 percent to 230 percent. The largest jump was that of Italy, where the ratio rises from 1.1 to 640 percent.

In panel $1 \mathrm{C}$ we see broadly similar patterns with growth of foreign currency trading. Since the collapse of Bretton Woods in 1973, the rise in currency trading and the gross flows of financial assets across borders is unprecedented. As we see, the ratio of daily foreign exchange turnover relative to the reserves of all central banks has risen spectacularly, from 6.8 percent of central bank reserves to 97.7 percent of reserves in 1995. In the aftermath of the Asian financial crisis, the ratio falls back somewhat to 91.7 percent between 1995-98. However, there is no expectation of the ratio continuing to fall to levels comparable to those of the 1970s or 1980s.

\section{Effects of Financial Deregulation}

How have these financial patterns affected economic welfare? We consider this in terms of both short- and long-run effects.

\section{Short-term effects.}

The rise of short-term financial flows has made economies much more susceptible to financial crises. Among other factors, the very expansion of financial trading makes it more difficult for governments to control the inevitable periods of financial herd behavior. Once a financial crisis has broken out and government must try to neutralize a stampeding financial herd, their capacity to intervene effectively will be smaller when the size of the stampede is relatively large. The logic of this is clear in the case of contemporary foreign exchange markets. Precisely because daily trading on these markets has risen from 6.8 percent of central banks' foreign currency reserves in 1977 to between 90 - 100 percent over the 1990s, central banks have far less capacity to serve as a market-maker to counteract speculative stampedes. ${ }^{20}$

This situation is consistent with the data on financial crises over the past 20 years. According to a study published by the IMF itself, nearly three-fours of the 182 members of the IMF, including a substantial number of developed countries, suffered one or more bouts of banking crises or "significant banking problems" during 1980-95 (Lindgren, Garcia and Saal 1996). Banking crises, defined in this IMF survey as "cases where there were runs or other substantial portfolio shifts, collapses of financial firms, or massive government intervention" afflicted 36 countries. "Significant banking problems" defined as "extensive unsoundness short of crisis," afflicted another 108. The recent Asian crisis and its repercussions have since raised these numbers significantly.

\footnotetext{
${ }^{19}$ But even this 23.7 figure for 1997 is a conservative estimate, in that, for purposes of comparability across the full period, we exclude the category "uncommitted facilities", as reported by the OECD for this year. Had we included these "uncommitted" as well as the "committed facilities" in our total for funds raised, the ratio of funds raised/exports for 1997 would be about 30 percent.

${ }^{20}$ Felix $(1998,2001)$ considers this issue in some detail.
} 
An analysis of 26 developing and industrialized countries suffering banking and currency crises during 1980-95 found that financial sector liberalization within the five years preceding the crisis accurately predicted 67 percent of the banking crises and 71 percent of the currency crises. Liberalization, by broadening access to foreign funds, had encouraged domestic banks and companies to raise their liability leveraging to crisis levels. ${ }^{21}$

The social and economic costs of frequent crises have been substantial. A World Bank study of a sample of developing country banking crises estimates that during the crises GDP declined 14.6 percent below its trend-line growth. The study also points out that banking crises have become intertwined with currency crises due to "surges of international capital inflowsespecially private-to-private flows - to developing countries and the growing integration of these economies with world financial markets." The cost of these twin crises have also been much higher than for each occurring in isolation, averaging 18 percent of GDP in developing countries and 17.6 percent in industrialized countries. Moreover, Lustig (2000) shows that financial crises reduce the likelihood for the poor to escape poverty through economic growth because they are ill-equipped to weather the adverse macroeconomic shocks.

\section{Long-term effects}

Long-term interest rates. Paralleling the explosive post 1970s growth of international capital flows has been the sharp rise of long-term real interest rates. The figures in Table 2 on U.S. long-term real rates give an indication of the world-wide pattern. As we see in the table, the 10-year Treasury Bond rate spiked at an average of 5.9 percent between 1980-84, after having ranged between $0.8-2.7$ percent over the five year periods between 1955-79. The rate does fall in subsequent five-year periods after 1980-84, though by 1995-99, only to a still historically high 4.3 percent.

\section{TABLE 2 BELONGS HERE}

The deregulation of financial markets has very likely played a major role in generating this pattern. A recent OECD econometric study (Orr, Edey and Hviding 1995) has calculated that about half the rise of real long-term interest rates in the 1980s was due to financial deregulation. Felix (2001) proposes one causal link:

Prior to decontrol, when the monetary authorities lowered short-term interest rates to stimulate the economy, the major holders of long-term bonds, notably insurance companies and private pension funds, anticipated, rightly or wrongly, inflationary consequences. However, since fiduciary restrictions blocked them from holding stocks, they could merely move funds from longer to shorter-maturity bonds. Capital decontrol gave them the opportunity to move funds instead between home and foreign bond markets in pursuit of higher yields. That pushed up long-term rates, and to a lesser degree, short-term rates as well, and undermined the effort to stimulate the economy by monetary easing. (Felix p. 40).

Other factors are also at play, including the trend rise in the demand for credit by households and businesses in the U.S,--i.e. rising credit demand - accompanied by the shift in monetary policy in favor of inflation-targeting, i.e. a tightening of credit supply. Note that these

\footnotetext{
${ }^{21}$ The evidence presented in this and the next paragraph are from the World Bank (1998/99), cited at length in Felix (2001).
} 
demand and supply considerations operated initially in a period of relatively large government deficits throughout the world, but persisted as the deficits were eliminated-suggesting that the government-deficit "crowding out" explanation for high real interest rates, at the least, must be placed in a broader analytic context. ${ }^{22}$

Short-termism Excessively speculative financial markets tend to encourage short-term thinking among both investors and managers. The highly liquid financial markets enable investors to sell assets at low transaction costs whenever they are dissatisfied with a firm's performance, in response, for example, to a firm's unsatisfactory quarterly return. This creates persistent pressure for short-term success, to which managers in turn respond by gearing their investment projects and ongoing operations to satisfying the short-term horizons of financial market investors. As a result, highly speculative financial markets tend to excessively discount projects which require long-term nurturing before generating profitable returns.

These pressures become stronger still when real interest rates remain at persistently high levels. The "hurdle rate" is the cost of capital for a project plus the waiting premium. A higher real interest rate, as a major component of both the cost of capital and the discount factor, raises the hurdle rate for all projects, but it does so unevenly. It tilts investment decisions toward projects with lower fixed costs and shorter lags. ${ }^{23}$

These factors, in turn, create a bias in favor of merger and acquisition activity-i.e. asset purchases as opposed to asset creation. Thus, M\&A rose in the U.S. from 15.7 percent of gross private investment in 1981 to 47.8 percent in 1996 (Security Industry Fact Book 1997).

\section{$\underline{\text { Transformation of Macroeconomic Policy Objectives }}$}

The increasing size and volatility of deregulated financial markets has led to a profound shift in macroeconomic policy objectives throughout the world. During the Bretton Woods era, macroeconomic policy was concerned with domestic employment as well as financial stability and inflation. But increasingly since the 1970s, macroeconomic policy has been focused on achieving minimal if not zero inflation rates via generally tight, and frequently austere, fiscal and monetary policy regimes. ${ }^{24}$ In particular, fiscal policy interventions in behalf of employment expansion have been almost completely abandoned.

To a substantial extent, this shift in macroeconomic policy goals is a reaction to the pressure governments feel to retain the confidence of volatile financial markets. ${ }^{25}$ The new

\footnotetext{
${ }^{22}$ Pollin (1997) provides a framework for exploring these demand and supply shifts.

${ }^{23}$ These effects are discussed well in Poterba and Summers (1995). Their paper is particularly useful since it was written at a time when the advance of financial deregulation was less further along in so-called "bank-based" financial systems, and serves as a marker as to how quickly the global markets have changed due to deregulation.

${ }^{24}$ Epstein (2000) provides an analytic survey of the literature on this topic, especially as focused on monetary policy.

${ }^{25}$ This view was recently lent support by former Federal Reserve Vice Chair Alan Blinder (1998), who writes, "So far I have spoken about (central bank) independence from the rest of government...this sort of independence is what people seem to have in mind when they talk about independent central banks...But there is another type of independence that, while just as important in my view, is rarely discussed: independence from the financial markets....my point is... that delivering the policies that markets expect or indeed demand - may lead to very poor policy. This danger is greater now than ever, I believe, because the currently-prevailing view of financial markets among central bankers is one of deep respect. The broad, deep, fluid markets are seen as repositories of enormous power and wisdom. In my personal view, the
} 
macroeconomic policy regime has been most fully formalized through the establishment of the European Monetary Union. Membership in the Union requires abandonment of an active fiscal posture. In terms of monetary management, the bank is committed to maintaining strict inflation targets, even apparently in the face of deflationary forces such as prevailed in 2001. The U.S. has been somewhat less stringent, but primarily because the pressures of the reserve army of labor in the U.S. has dampened upward wage pressure at low unemployment. ${ }^{26}$ These same principles have been adopted throughout the developing countries as well, as they accept a macroeconomic regime governed by either dollarization of their currency or a currency board regime. ${ }^{27}$

\section{The Polanyi Problem}

The period in which big government capitalism was built was the aftermath of the 1930s Depression, World War II, and the developing worldwide competition with Communist governments. In this context, Karl Polanyi made a forceful case in his classic work The Great Transformation (1944) that for market economies to function with some modicum of fairness, they must be embedded in social institutions that effectively promote broadly accepted notions of the common good.

Various social democratic movements within the advanced economies adapted the Polanyi perspective. They argued in favor of government macroeconomic interventions to achieve three basic ends: stabilizing aggregate demand at some reasonable approximation of full employment; creating a financial market environment that is stable and conducive to the efficient allocation of investment funds; and distributing equitably the rewards from high employment, macroeconomnic stability and efficiency in investment allocations. The political ascendancy of these ideas were the basis for a dramatic increase in the government expenditure/GDP ratio throughout Japan, North America and Western Europe.

But the implementation of a social democratic capitalism was never a consensus position. Many sectors of capital opposed efforts to sustain full employment because, as we have seen, full employment engenders greater bargaining power for workers in labor markets, even while it also increases the economy's total output of goods and services. ${ }^{28}$ Greater worker bargaining power can also create inflationary pressures, and inflation will, in turn, depreciate the value of rentiers' portfolio of assets with nominally fixed values. In addition, market-inhibiting financial regulations limit the capacity of rentiers to both diversify risk and speculate.

Hence, it should not be surprising that capitalists and rentiers would utilize their increased bargaining power in labor and financial markets to also change the direction of government policy in behalf of their own ends. The issue here, moreover, is not deregulation of markets per se. Rather it is that markets be deregulated to support the interests of capitalists and rentiers, even as these same groups still benefit greatly from many forms of government support, including investment subsidies, tax concessions, and central bank rescue operations during financial crises. At the same time, the deregulation of markets that favors capitalists and rentiers is correspondingly the most powerful regulatory mechanism limiting the demands of workers, in that deregulation has been congruent with the worldwide expansion of the reserve army of labor

power is beyond dispute, but the wisdom is somewhat suspect," (pp. 60-62).

${ }^{26}$ This issue is discussed in some detail in Pollin (2002).

${ }^{27}$ Some recent literature on this issue includes Santiprabhob (1997), and Grabel (2000).

28 The classic statement of this problem is by Kalecki (1971). 
and the declining capacity of national governments to implement full-employment macroeconomic policies.

Of course, changes in the global economic environment have been of major significance in shifting the terms of the Polanyi problem. As we have discussed, the main economic effects of globalization has been through making possible both the rise of export competitive manufacturing industries in low-wage countries and the explosion of financial market trading levels. These factors, in turn do create difficulties for maintaining effective government interventions consistent with a broad Polanyi policy agenda. At the same time, these changes in the economic environment do not impose insuperable obstacles to advancing effective alternatives to neoliberalism. Quite the contrary: taking the full measure of the difficulties they impose is actually the first step toward advancing a viable alternative agenda. The intellectual challenge is therefore to advance new policy regimes that are able to transcend the real constraints imposed by globalization - that is to say, to recapture momentum, in the sense of Keith Griffin, toward a transition to egalitarian development.

\section{Elements of an Alternative Policy Framework}

\section{Maintaining perspective on international cooperation}

Given that the problems at hand are global, it is perhaps inevitable that we initially focus attention on policy measures that offer similarly global scope. Measures to promote international policy coordination clearly fall within this category of proposals. An important example of such a proposal is the plan advanced by Eatwell and Taylor (2000) for a new Global Financial Authority. The primary purpose of the Global Financial Authority would be to regulate and stabilize financial markets, and thereby create space for national governments to coordinate employment-expanding macroeconomic policies. Such proposals certainly have merit. However, the reliance on international cooperation as the leading edge of an alternative progressive policy agenda also has serious flaws.

The failings of the existing policy framework are by no means due to a lack of institutions and policies supporting global economic cooperation. After all, the IMF, World Bank, and WTO do themselves already operate on the basis of international cooperation. The problem is not the lack of international cooperation per se, but that these institutions promote cooperation in behalf of neoliberalism. The need, therefore, is not to simply create another such transnational institution, but to build a viable international constituency for an egalitarian alternative to neoliberalism.

\section{$\underline{\text { Features of an Alternative Agenda }}$}

I concentrate here on only three interrelated policy areas: 1) financial market regulation; 2) employment-targeted macroeconomic policies; and 3) labor market regulation. I also offer brief observations on a broader range of policy questions, including trade policy, industrial policy and foreign direct investment, and redistributionist welfare-state policies. But as I will try to show, employment policies along with regulations of financial and labor markets are best suited to provide the foundation of a new egailatarian policy agenda.

The logic of our foregoing discussion suggests that we begin this policy discussion in the area of financial markets. This is because the explosion of financial market trading and corresponding increase in financial market volatility has led to the shift in the aims of macroeconomic policy away from employment-targeting. If an effective set of financial market 
regulations can be constructed, this will allow for macroeconomic policy to return to the goal of employment-targeting while also maintaining control over inflationary pressures. Having macroeconomic policy concerned with employment targeting will thus create stronger foundation on which to construct effective labor market regulations.

\section{Financial market regulation}

Three basic principles should guide the formulation of a new financial market regulatory regime. First, the regulatory environment should be consistent in the way that it affects all intermediaries and markets; in other words, following D'Arista and Schlesinger (1993), that policy engender an upward leveling of the regulatory environment. Such an approach minimizes opportunities for rent seeking through exploiting regulatory differences among market segments. A consistent regulatory structure is also easier to design, implement and enforce. The second principle is that, as much as possible, regulations should work through altering market prices and incentives rather than establishing hard limits on market activity. This is a point that that Keith Griffin has long emphasized - to achieve the benefits of regulations while also maintaining market flexibility to the greatest possible extent. The third principle is the promotion of financial market activities in which social rates of return exceed private rates. The U.S. Glass-Steagall system, for example, heavily supported the social goal of financing of individual-family housing, through limiting the assets of savings and loan institutions to mortgage loans.

This is not to say that determining social rates of return is always straightforward. But one clear choice would be to weight heavily the benefits accruing through financial stability itself. Thus, any new regulatory environment should seek to limit the immediate sources of instability-herd behavior, the contagion effects of market trends, and the spillover effects from financial market activity to the broader economy.

Two specific policy measures that are consistent with all three of these broad principles are asset-based reserve requirements and security transaction excise taxes. Asset-based reserve requirements would include Basel-type capital adequacy requirements, margin requirements on stock trading, and requirements limiting the composition of loans, such as had applied to savings and loans under the Glass Steagall system. When they operate properly, such measures enable regulators to establish differential carrying costs to financial institutions according to the quality of the assets in their portfolio. Thus, if financial market stability is the social outcome sought by such measures, then loans from regulated intermediaries that finance speculative trading would carry higher reserve or margin requirements. The same technique is capable of promoting other goals as well, as was the case under Glass-Steagall with individual-family housing.

Of course, such measures are always limited in their effectiveness. For example, the 1988 Basel regulations have clearly been incapable of providing any serious constraints on speculative lending. The Basel committee, as of this writing, has been in the process of reforming its regulations, even while it acknowledges the likely limitations of a new set of regulations as well. However, the new set of Basel measures should also create the possibility for a broader set of constituencies to be represented among regulators. This alone could alter the dynamics of regulation in a way that enhances their stability properties. ${ }^{29}$

Securities transaction excise taxes, such as the so-called "Tobin tax" on foreign exchange markets, are an efficient way of raising the costs of short-term speculative trading in financial markets, as opposed to trading for the purpose of long-term asset holding. Following the

\footnotetext{
${ }^{29}$ Felix (2001) summarizes the evolution and current problems with Basel capital adequacy requirements.
} 
principle that regulations should be consistent across market segments, the tax should be imposed not simply on foreign exchange markets, as with Tobin's initial proposal, but consistently across all markets.

The idea of the tax is that it allows the market to screen out speculative from more stable financial flows. This is because a small tax on a security transaction--for example a 0.5 percent tax on a equity trades--would create a negligible burden on asset owners who intend to hold their asset for the long-term. However, if asset owners purchase a new stock with the intention of selling it at a profit in the short-term, the 0.5 percent tax would be imposed on each trade, and would thus constitute a significant burden.

Proposals for these taxes have faced substantial criticism in recent years, in particular around the point that imposing them necessarily creates serious market distortions and thereby new opportunities for rent-seeking. But in fact, such measures can be implemented in a workable fashion across financial market segments. ${ }^{30}$

\section{Employment-Targeted Macroeconomic Policy}

It is well-known that in a purely demand-constrained economy, it is not difficult to induce an employment-targeted expansion by deploying standard fiscal and monetary tools. But economies are rarely constrained strictly by demand, especially within a globally-integrated economic environment. Depending on the country, an array of additional constraints can limit the expansionary impulse of a demand-centered policy intervention, such that the initial expansion of employment and output will not be sustainable. The most general such constraints include the effects of expansion on inflation, interest rates, and exchange rates. They also include the dissipation of the force of an expansion through import, saving, and what we call speculative leakages, this being the unproductive trading of existing assets rather than the creation of new productive assets. Let us focus here on two of the most serious such constraints, import leakages and inflation.

In terms of import leakages, it is useful to consider this question within two contexts. The first is international coordination of expansion. Clearly, if coordination is effectively executed, then the problem of import leakages should be minimized. But even in the absence of coordinated expansion, import leakages can be significantly reduced by paying careful attention to the output composition of expansion. An expansion of domestic demand can be led by private consumption, private investment, public consumption or public investment. Of these a public investment-led expansion is best suitied to minimize import leakage since the first round of expansionary spending is conducted entirely by the government itself. Well-executed public investment expenditures will also promote longer-term productivity growth, and is therefore an efficient means of expanding aggregate supply as well as aggregate demand. ${ }^{31}$

\footnotetext{
${ }^{30}$ Pollin, Baker and Schaberg (2001) surveys the literature on securities transaction taxes and offers a design proposal that would allow the tax to operate neutrally across segments of the financial services industry. Ul Haque, Kaul and Grunberg (1996) is a useful collection on tax as it would apply within foreign exchange markets only.

${ }^{31}$ Pollin (1998b) reviews the relevant literature on public investment and expansionary policy. Much of this essay was inspired by work I did with Keith Griffin in Bolivia in the early 1990s. Griffin designed a public-investment led expansionary program for Bolivia focusing on the rural sector that was viable at both a macro- and micro-level-since it increased micro-efficiency while also expanding employment and jobs.
} 
In terms of inflation, Epstein (2000) and Bruno (1995), among others, have shown that short of hyper-inflationary situations, inflation does not inhibit economic growth. Indeed, according to both Epstein and Bruno, increases in inflation are more consistently correlated with higher growth rates. But in a positive growth environment, inflation alters the distribution of wealth and income. In part, these distributional changes are unpredictable, since they depend on a country's system of indexation and the relative rates at which different sectors of society are able to achieve nominal income gains. Still, a broadly predicable distributional change of inflation is that it will bring wealth and income losses for those holding assets that are nominally fixed in value. Such losses would therefore tend to be concentrated among rentiers more than other social groups. This in turn explains the strong opposition of "the bond market" to signs of inflation.

In any case, the distributional costs of inflation need to be controlled so that the benefits of employment-targeted macro policies are sustainable. The experience in Sweden over the 1960s-1980s offers important lessons here. The Social Democratic government in power practiced a creative combination of macro and incomes policy to sustain high employment, egalitarian income distribution, and low inflation. Among other measures, fiscal and monetary policy were used to bring unemployment to around 3-4 percent, i.e a low level but one that still maintained a degree of labor market slack. This prevented excessive inflationary pressures. From this point, the Swedish policy was to engage in highly active microeconomic labor market interventions - including retraining programs and extensive job placement services - to minimize frictional unemployment. ${ }^{32}$

\section{$\underline{\text { Labor Market Regulations }}$}

Assuming that a sustainable high employment regime can be effectively promoted through the appropriate combination of financial market regulations and employment-targeted macro policies, the point of labor market regulations will be to enable working people to share in the benefits of financial stability and growth. The labor market regulations that are of central importance operate along three dimensions: workplace conditions, including standards of cleanliness and safety; the rights of workers to associate, grieve, and organize; and the establishment of decent minimum standards for wages and benefits.

As a first principle, the single most effective form of social protection for workers is a tight labor market. However, tight labor markets are not a sufficient condition for providing an equitable sharing of the benefits of growth. Moreover, labor market regulations must also contribute to dampening inflationary pressures, as was the case with the Swedish model of minimizing frictional unemployment through labor market policies. Such issues obviously need to be address.

\section{$\underline{\text { Advanced Economies }}$}

United States. The inadequacy of labor market tightness as a guarantor of equitable labor market outcomes was made clear during the experience with the last full business cycle in the U.S., 1991-2000. The unemployment rate did fall sharply over this period, and without setting off a cycle of accelerating inflation. Despite this, wage inequality also increased and the average wage stagnated through 1996. Even after 4 years of wage increases from 1997-2000, the average

\footnotetext{
${ }^{32}$ Discussions of the Swedish macro/labor market model are presented in Pekkarinen, Pohjola, and Rowthorn (1992) and Meidner (1998).
} 
real wage by 2000 remained 10 percent below the peak of $1973 .{ }^{33}$ For the gains from such growth to be more equitably shared will entail a shift in the institutional setting of wage bargaining - including higher minimum wages, and more generally, a more supportive political and legal environment in which workers can collectively advance their interests.

Europe. The widely accepted premise in Europe is that excessive labor market regulations already exist. Indeed, from this perspective, reducing these regulations-i.e. increasing "labor market flexibility" - is the only viable solution to Europe's unemployment problems (e.g. Bean 1994 and Siebert 1997). But as Glyn and Salverda (2000), among others, show, employment protection legislation, the generosity of minimum wages, and unemployment benefits are all without discernible impact on employment rate differences across OECD countries. The suggestion flowing from this research is that European workers need not relinquish the gains they have won over the past two generations in the area of regulations. Renovations of the existing regulatory systems are no doubt in order in many cases. But as a general matter, European labor market regulations have achieved standards from which other regions of the world can profitably learn.

\section{Developing Countries}

Here, of course, a separate set of issues becomes important because of the large number of workers employed in the informal sector, where, by definition, regulations governing workplace conditions, workers' rights of association, and minimum wages either do not exist or, if they exist, are routinely ignored. Thus, in addition to producing a regulatory environment that enhances workplace conditions, ensures a reasonable bargaining environment and establishes a decent minimum wage floor, the aim of labor market regulations in developing countries should be to broaden the reach of formal sector employment itself.

Of course, the purpose for labor market regulations in developing countries is controversial, given the facts of mass poverty and underemployment. Even prohibitions on child labor have been challenged by serious analysts (e.g. Basu 1999), since the alternative to legal employment opportunities for children may be even less acceptable, including the drug trade or prostitution. More generally, increasing labor regulations should induce corresponding increases in labor costs, which can in turn weaken export competitiveness. In a series of econometric exercises, Rodrik (1996) has found that an index number proxying for labor standards does indeed vary positively with labor costs.

But recent research I have done with two colleagues (Pollin, Burns and Heintz 2003) has posed a more direct question as regards the relationship between labor costs and employmentthat is, what is the relationship, by country, between real wage and employment growth in the global apparel industry? The apparel industry is an important case to study here, since, among manufacturing industries, its low fixed costs promote a high degree of capital mobility. Our regression analysis finds no statistically significant relationship at all between real wage and employment growth, either through examining a sample of 45 OECD and non-OECD countries, or through narrowing the sample to 27 non-OECD countries alone.

These conclusions were based on a series of bivariate regressions, so they are not sufficiently well-specified to explain why no relationship exists between real wage and employment growth. But they do enable us to conclude that, both in the advanced and developing economies, other factors can dominate over wage rates alone in establishing a viable

${ }^{33}$ Mishel, Bernstein and Schmitt (2000) provide the relevant evidence on these trends. 
apparel manufacturing industry. This in turn implies that labor market regulations, which collectively will yield rising labor costs, does not necessarily entail a loss of viable manufacturing industries, even in a highly mobile sector such as apparel.

\section{Broader Policy Implications}

There is a one simple point that I wish to stress here - that the context within which one considers trade, industrial policy, foreign direct investment and the welfare state will be substantially changed within the macroeconomic and regulatory environment that I have sketched as against a neoliberal policy regime. This is the process through a transition to egalitarian develop advances outward from its foundation.

\section{Trade Policy}

A first point that emerges from the foregoing discussion is that trade opening and financial market liberalization should not be treated in parallel fashion. Rather, what becomes clear within our alternative framework is that tight regulations of speculative financial flows is a necessary precondition for the gains from trade opening to be sustainable. Open trading is persistently disrupted and ultimately becomes unsustainable when financial markets, including foreign exchange markets, fluctuate heavily and experience regular crises.

Moreover, the welfare losses to workers from trade opening that we have described under the Marx problem would not occur to nearly the same extent in our alternative policy framework. This is because, in both the North and South, active employment policies and labor market regulations would operate to support the welfare of working people. These would act as direct forms of social protection that would almost always be more effective than trade policy at raising the welfare of the majority. At best, trade policy is an indirect and inefficient means of providing social protections.

A second issue with trade is the extent to which countries should stress export-promotion as a primary growth engine. The results that we report in "the Marx problem" section of the paper show that export promotion policies have not led to broad gains in employment among developing countries. We would also not expect these patterns to change substantially in the future. This does not mean that developing countries should abandon efforts at export promotion. But it does follow that the case for expanding domestic markets through higher levels of employment at rising wages should return as a viable feature of development policy. Indeed, considering export-promotion and domestic market expansion as incompatible alternatives is the most serious error here. The stress should be on maintaining a viable employment environment, while also promoting higher productivity through active industrial policies. Both trade and foreign direct investment can play important roles in this broader policy framework, but they need not be seen as the dominant focus of policy.

Finally, independently of other considerations regarding trade policy, there continues to be an important argument for maintaining tariffs in the case of developing countries. Perhaps the single most neglected issue regarding trade liberalization has been its impact on the fiscal revenues of developing countries, and hence on the governing capacity of the state for these countries. Rao (1999) has shown that for low and middle-income countries trade taxes provide a major share of overall tax revenue, frequently being the government's largest single source of revenue. But trade liberalization has meant that revenue from trade taxes have fallen substantially. Thus, for low-income countries, trade tax revenues constituted 40.8 percent of total revenue from 1970-75. This figure then falls steadily, such that by 1991-96, it constitutes 32.2 
percent of total revenue. Rao goes on to explore the difficulties low- and lower-middle income countries face in successfully generating alternative sources of revenue. The result has been that trade liberalization has led to significant declines in total tax revenues, and thus a squeeze on fiscal activities.

\section{Foreign Direct Investment and Industrial Policy}

The context in which one evaluates the effects of foreign direct investment will also change within the policy framework we propose. First, through regulating speculative financial flows, the distinction between the effects of speculative finance and longer-term "patient" foreign investment would become clearer. Moreover, in a policy regime committed to high employment and social protections for workers, the power of exit threats by footloose firms should diminish. For one thing, workers would not feel as personally vulnerable to such threats. Crotty, Epstein and Kelly (1998) present three general conditions that will determine the extent to which host countries benefit from foreign direct investment. These are the state of aggregate demand, the nature of investment regulations, and a similar set of regulations regarding competition.

But in addition, as Chang (1998) has argued, transnational firms are attracted to countries as production sites not primarily because they offer low labor costs and taxes. Rather, Chang contends that transnational firms are especially attracted to production locations that can offer rapid economic growth, a reliable productive infrastructure, a trained workforce, as well as political stability. China is the primary the primary case in point here. It received over 25 percent of all developing countries' foreign direct investment between 1990-94, despite having placed quite restrictive regulations on transnational firms.

More generally, we see that the policy measures central for attracting foreign direct investment on favorable terms - providing a well-functioning public infrastructure and skilled workforce-also bring us back to other areas of concern within our overall policy framework. For one thing, we have argued earlier as to the macroeconomic benefits of public infrastructure investments as the major growth node of macroeconomic expansionary programs. Also, the need to maintain sufficient public revenues is important for supporting education and training programs.

Using differential asset reserve requirements as a financial regulatory measure offers still additional connections with industrial policies, though here more with the promotion of domestic rather than foreign investment. Indeed, a major feature of the East Asian miracle economies was the strategic deployment of low-cost credit to promote export-competitive firms.

\section{$\underline{\text { Welfare State Policies }}$}

Proposals in the areas of employment and labor market policies clearly have direct relevance here. Expanding the supply of good jobs is clearly the centerpiece of this renovated egalitarian policy regime. However, we should not expect that increasing the supply of good jobs would be sufficient by itself to sustain distributional equity or alleviate poverty, either in the advanced or the developing countries. Among other considerations, in establishing decent employment standards - again both in the advanced and developing countries-- one does need to be concerned with how such standards will influence the competitiveness of the covered firms. If firm competitiveness is significantly weakened, this in turn could produce large-scale job losses. Thus, government redistributive policies, such as the Earned Income Tax Credit in the United States, can be useful in allowing that the costs of providing workers and their families with a decent minimum living standard are shared between taxpayers and the firms that hire the workers. 
At the same time, when employment opportunities are more favorable, the welfare-improving responsibilities being carried by government redistributive measures will diminish. This yields the desirable outcome of redistributive policies operating as a supplement rather than as a substitute for effective employment policies.

\section{Conclusion}

Let me simply restate the basic arguments of the paper. They are:

1. The contemporary period of globalization is historically unique. It has resulted in part through technological breakthroughs. But it is more fundamentally the result of the prevailing neoliberal policy regime within which the impact of new technologies are being experienced.

2. Neoliberal policies do promote competitiveness and micro-efficiency under certain situations. But they also lead to the deepening of the Marx, Keynes and Polanyi problems in the contemporary global economy, both in the global North and the global South.

3. Alternatives to neoliberalism are not just desirable but also feasible. That is to say, transitions to egalitarian development, both in the global North and South, our within our grasp now. They begin with a careful rethinking of financial and labor market regulations and a reconstruction of employment-targeted macroeconomic policies. Once these key features of a new policy regime are in place, the terms under which we examine trade opening, foreign direct investment, industrial policy and the welfare state should all change substantially. In particular, the severe difficulties that frequently emerge in these policy areas under the prevailing neoliberal regime should be substantially ameliorated under alternative policy framework sketched here. 


\section{$\underline{\text { References }}$}

Alarcon, Diana, and Zepeda, Eduardo (1998) "Employment Trends in the Mexican Manufacturing Sector," North American Journal of Economics and Finance (9), pp. 125-45.

Baker, Dean, Epstein, Gerald, and Pollin, Robert, eds. (1998). Globalization and Progressive Economic Policy, Cambridge, UK: Cambridge University Press.

Baker, Dean, Epstein, Gerald, and Pollin, Robert, (1998). "Introduction," in their Globalization and Progressive Economic Policy, Cambridge, UK: Cambridge University Press, 1-34.

Basu, Kaushik (1999) "Child Labor: Cause, Consequences, and Cure, with Remarks on International Labor Standards," Journal of Economic Literataure, 37(3), pp. 1083-1119.

Bean, Charles R. (1994) “European Unemployment: A Survey,” Journal of Economic Literature 32(2), pp. 573-619.

Berman, Eli, Machin, Stephen, and Bound, John (1996) "Implications of Skill-Biased Technological Change: International Evidence,” NBER Working Paper 6166, Cambridge, MA: NBER.

Bhagwati, Jagdish and Dehejia, Vivek (1994) "Freer Trade and Wages of the Unskilled: Is Marx Striking Again? In Jaghish Bhagwati and Marvin H. Kosters, Trade and Wages: Leveling Wages Down? Washington, D.C.: American Enterprise Institute.

Blanchflower, D.G. and Oswald (1995) “An Introduction to the Wage Curve," Journal of Economic Perspectives, 9(3), pp. 153-167.

Blank, Rebecca (1997) "No Easy Answers: Comparative Labor Market Problems in the United States versus Europe," Northwestern University/University of Chicago Joint Center for Poverty Research Working Paper No. 188.

Blinder, Alan (1998) Central Banking in Theory and Practice, Cambridge, MA: MIT Press.

Braunstein, Elissa and Epstein, Gerald (1999). "Creating International Credit Rules and the Multilateral Agreement on Investment: What are the Alternatives?" in Michie, Jonathan and Grieve Smith, John eds., Global Instability: The Political Economy of World Economic Governance, London and New York: Routledge, 113-33.

Bronfenbrenner, Kate (1996). "The Effects of Plant Closing or Threat of Plant Closing on the Right of Workers to Organize." Report to the U.S. Department of Labor, September.

Bryceson, Deborah, Kay, Cristobal, and Mooij, Jos (2000) Disappearing Peasantries? Rural Labour in Africa, Asia, and Latin America, London: Intermediate Technology Publications.

Card, David and DiNardo, John (2002) "Skill-Biased Technological Change: Some Problems and Puzzles," Cambridge, MA: National Bureau of Economic Research Working Paper \#W8769.

Chang, Ha-Joon (1998) "Globalization, Transnational Corporations, and Economic Development: Can the Developing Countries Pursue Strategic Industrial Policy in a Globalizing World Economy?" in Baker, Dean, Epstein, Gerald, and Pollin, Robert, eds., Globalization and Progressive Economic Policy, Cambridge, UK: Cambridge University Press, pp. 97-113.

Cline, William R. (1997) Trade and Income Distribution, Washington, D.C.: Institute for International Economics. 
Crotty, James (1994) “Are Keynesian Uncertainty and Macrotheory Compatible? Conventional Decision Making, Institutional Structures, and Conditional Stability in Keynesian Macromodels," in Dymski, Gary and Pollin, Robert, New Perspectives in Monetary Macroeconomics: Explorations in the Tradition of Hyman P. Minsky, Ann Arbor, MI: University of Michigan Press, pp. 105-142.

Crotty, James, Epstein, Gerald, and Kelly, Patricia (1998) "Multinational Corporations in the Neoliberal Regime," in Baker, Dean, Epstein, Gerald, and Pollin, Robert, eds., Globalization and Progressive Economic Policy, Cambridge, UK: Cambridge University Press, pp. 117-143.

D’Arista, Jane and Schlesinger (1993) “The Parallel Banking System,” in Dymski, Gary, Epstein, Gerald, and Pollin, Robert (1993) Transforming the U.S. Financial System: Equity and Efficiency for the $21^{\text {st }}$ Century, Armonk, NY: M.E. Sharpe, pp. 157-99.

Dymski, Gary, Epstein, Gerald, and Pollin, Robert (1993) Transforming the U.S. Financial System: Equity and Efficiency for the $21^{\text {st }}$ Century, Armonk, NY: M.E. Sharpe.

Eatwell, John and Taylor, Lance (2000). Global Finance at Risk: The Case for International Regulation, New York: The New Press.

Epstein, Gerald (2000) "Myth, Mendacity and Mischief in the Theory and Practice of Central Banking," manuscript, Political Economy Research Institute, University of Massachusetts-Amherst.

Felix, David (1998) Asia and the Crisis of Financial Globalization," in Baker, Dean, Epstein, Gerald, and Pollin, Robert, eds., Globalization and Progressive Economic Policy, Cambridge, UK: Cambridge University Press, pp. 163-191.

Felix, David (2001) "Why International Capital Mobility Should be Curbed, and How it Could Be Done," paper prepared for the International Confederation of Free Trade Unions (ICFTU), Brussels, Belgium.

Fortin, Nicole M. and Lemieux, Thomas (1997). "Institutional Changes and Rising Wage Inequality: Is There a Linkage?" Journal of Economic Perspectives 11(2), 75-96.

Ghosh, Jayati (2000) "Exporting Jobs or Watching Them Disappear? Relocation, Employment and Accumulation in the World Economy," Draft paper presented at IDPAD Conference on Globalization, Structural Change and Income Distribution, Chennai, India, December 2000.

Glyn, Andrew (1995) “The Assessment: Unemployment and Inequality,” Oxford Review of Economic Policy 11(1), pp. 1-25.

Glyn, Andrew and Salverda, Wiermer (2000) “Does Wage Flexibility Really Create Jobs?” Challenge, January-February, 2000, pp. 32-43.

Gordon, David M. (1988). “The Global Economy: New Edifice or Crumbling Foundations?” New Left Review, 168, 24-65.

Grabel, Ilene (1997) "Savings, Investment, and Functional Efficiency: A Comparative Examination of National Financial Complexes," in Pollin, Robert, ed., The Macroeconomics of Saving, Finance, and Investment, Ann Arbor: University of Michigan Press, pp. 251-98.

Grabel, Ilene (2000) “The Political Economy of 'Policy Credibility': the New Classical Macroeconomics and the Remaking of Emerging Economies," Cambridge Journal of Economics 24(1), pp. 1-19.

Griffin, Keith and James, Jeffrey (1981) The Transition to Egalitarian Development: Economic Policies for Structural Change in the Third World, London: MacMillan. 
Griffin, Keith (1994) "Regulating World Markets in a Liberal Global Economy,” Working Paper \# 94-32, Department of Economics, University of California-Riverside.

Griffin, Keith (1997a) "Culture, Human Development and Economic Growth,", Occasional Paper Series on Culture and Development, New York: United Nations Research Institute for Social Development.

Griffin, Keith (1997b) “Globalization and Development Cooperation: A Reformer's Agenda," in Albert Berry, Roy Culpeper and Frances Stewart, eds, Global Goverance and Development Fifty Years After Bretton Woods, London: MacMillan.

Griffin, Keith (199a) "Culture and Economic Growth: The State and Globalization," Indian Journal of Applied Economics, 8:2, April-June.

Griffin, Keith (1999b) "Globalization and the Shape of Things To Come," Macalester International, Vol 7, Spring.

Howell, David, Duncan, Margaret, and Harrison, Bennett (1998) "Low Wages in the U.S. and High Unemployment in Europe: A Critical Assessment of the Conventional Wisdom," Working Paper \#5, Center for Economic Policy Analysis, New School University.

Howell, David (1999a). “Theory-Driven Facts and the Growth of Earnings Inequality," Review of Radical Political Economics, 31(1), 54-86.

Howell, David (1999b) "Demand Shifts and Earnings Inequality: Wage and Hours Growth by Occupation in the U.S., 1970-97," Report to the Rockefeller Foundation, Center for Economic Policy Analysis, New School University.

Kalecki, Michal,(1971). "Political Aspects of Full Employment," Ch. 12 of his Selected Essays on the Dynamics of the Capitalist Economy, Cambridge, UK: Cambridge University Press, 138-145.

Keynes, John Maynard (1936) The General Theory of Employment, Interest, and Money, New York: Harcourt Brace \& World.

Kindleberger, Charles (1977). Manias, Crashes and Panics: A History of Financial Crisis, New York: Basic Books.

Krugman, Paul (1994). "Past and Prospective Causes of High Unemployment," in Federal Reserve Bank of Kansas City, Reducing Unemployment: Current Issues and Policy Options.

Larudee, Mehrene (1998) "Integration and Income Distribution Under the North American Free Trade Agreement: the Experience of Mexico," in Baker, Dean, Epstein, Gerald, and Pollin, Robert, eds., Globalization and Progressive Economic Policy, Cambridge, UK: Cambridge University Press, pp. 273-292.

Layard, Richard, Nickell, Stephen, and Jackman, Richard (1991) Unemployment: Macroeconomic Performance and the Labour Market, Oxford,: Oxford University Press.

Lewis, W. A. (1955) “Economic Development with Unlimited Supplies of Labour," Manchester School of Economic and Social Studies Bulletin, 22, pp. 139-92.

Lindgren, Carl-Johan, Garcia, Gilliam, and Saal, Matthew (1996) Bank Soundness and Macroeconomic Policy, Washington, D.C.: International Monetary Fund.

Lustig, Nora (2000) "Crises and the Poor: Socially Responsible Macroeconomics," Sustainable Development Department Technical Paper Series No. POV-108, Washington, D.C.: Inter-American Development Bank. 
Meidner, Rudolph (1998) “The Rise and Fall of the Swedish Model,” Challenge, January-February 1998, 6990

Minsky, Hyman P. (1986) Stabilizing an Unstable Economy, New Haven, CT: Yale University Press.

Mishel, Lawrence, Bernstein, Jared, and Schmitt, John (2000) The State of Working America, Washington, D.C.: Economic Policy Institute.

Nurske, Ragnar (1953) Problems of Capital Formation in Underdeveloped Countries, Oxford: Oxford University Press.

OECD (1994a) OECD Jobs Study; Evidence and Explanations, Part I: Labour Market Trends and Underlying Forces of Change, Paris: OECD.

OECD (1994b) OECD Jobs Study; Evidence and Explanations, Part II: The Adjustment Potential of the Labour Market, Paris: OECD.

Orr, Adrian, Edey, Malcolm, and Hviding, Ketil (1995) "Real Long-Term Interest Rates: The Evidence from Pooled Time-Series," Paris: OECD Economic Studies, No. 25.

Panic, Mica (1995) “The Bretton Woods System: Concept and Practice," in Michie, Jonathan and Grieve Smith, John eds., Managing the Global Economy, Oxford: Oxford University Press, pp. 37-54.

Pekkarinen, Jukka, Pohjola, Matti, and Rowthorn, Bob, eds. (1992) Social Corporatism : A Superior Economic System? New York : Oxford University Press, c1992

Polanyi, Karl (1944). The Great Transformation, Boston: Beacon Press.

Pollin, Robert (1995) "Financial Structures and Egalitarian Economic Policy, International Papers in Political Economy 2(3).

Pollin, Robert (1997) "Financial Intermediation and the Variability of the Saving Constraint," in Pollin, Robert, ed., The Macroeconomics of Saving, Finance, and Investment, Ann Arbor: University of Michigan Press, pp. 309-366.

Pollin, Robert (1998a) “The 'Reserve Army of Unemployed' and the 'Natural Rate of Unemployment': Can Marx, Kalecki, Friedman, and Wall Street All Be Wrong?" Review of Radical Political Economics, Summer 1998, 1-13.

Pollin, Robert (1998b). "Can Domestic Expansiony Policies Succeed in a Globally Integrated Environment? An Examination of Alternatives," in Baker, Dean, Epstein, Gerald, and Pollin, Robert, eds., Globalization and Progressive Economic Policy, Cambridge, UK: Cambridge University Press, pp. 433-460.

Pollin, Robert (2002) Contours of Descent: U.S. Economic Fractures and the Landscape of Global Austerity, London: Verso Press.

Pollin, Robert, Burns, Justine, and Heintz, James (2003) "Global Apparel Production and Sweatshop Labor: Can Raising Retail Prices Finance Living Wages?" Cambridge Journal of Economics, forthcoming.

Pollin, Robert, Baker, Dean and Schaberg, Marc, (2001) "Securities Transaction Taxes for U.S. Financial Markets, Working Paper No. 20, Political Economy Research Institute, University of Massachusetts-Amherst. 
Poterba, James and Lawrence H. Summers (1995) "A CEO Survey of U.S. Companies' Time Horizons and Hurdle Rates," Sloan Management Review 37 (Fall ), 43-53.

Rao, Mohan (1999) "Globalization and the Fiscal Autonomy of the State," Background Paper for the Human Development Report, 1999, Human Development Report Office, New York: United Nations Development Program.

Reardon, Thomas, Berdegue, Julio, and Escobar, German (2001) "Rural Nonfarm Employment and Incomes in Latin America: Overview and Policy Implications," World Development 29(3), 395409 .

Reardon, Thomas, Stamoulis, K., Balisacan, A., Cruz, M.E., Berdegue, J., and Banks, B. (1998) "Rural Nonfarm Income in Developing Countries," Special Chapter in The State of Food and Agriculture 1998. Rome: Food and Agricultural Organization of the United Nations, pp. 283-356.

Rodrik, Dani (1996) "Labor Standards in International Trade: Do They Matter and What Do We Do About Them?" in Lawrence, Robert Z., Rodrik, Dani, and Whalley, John, Emerging Agenda for Global Trade: High Stakes for Developing Countries, Overseas Development Council Essay No. 20, Washington, D.C.: Johns Hopkins University Press.

Rodrik, Dani (1997). Has Globalization Gone Too Far? Washington, DC: Institute for International Economics.

Santiprabhob, V. (1997) "Bank Soundness and Currency Board Arrangements: Issues and Experience," IMF Working Paper on Policy Analysis and Assessment, No. 11.

Schaberg, Marc (2000) Globalizsation and the Erosion of National Financial Systems: Is Declining Autonomy Inevitable? Northampton, MA: Edward Elgar Publishers.

Shiller, Robert J. (2000) Irrational Exuberance, Princeton, NJ: Princeton University Press.

Shleifer, Andrei (2000) Inefficient Markets: An Introduction to Behavioral Finance, New York: Oxford University Press.

Siebert, Horst (1997) “Labor Market Rigidities: At the Root of Unemployment in Europe," Journal of Economic Perspectives, 11(3), 37-54.

Sutcliffe, Bob and Glyn, Andrew (1999). "Still Underwhelmed: Indicators of Globalization and their Misinterpretation," Review of Radical Political Economics 31(1), 111-32.

Stewart, Frances and Berry, Albert (1999) "Globalization, Liberalization and Inequality: Expectations and Experience," in Andrew Hurrell and Ngaire Woods eds., Inequality, Globalization and World Politics, New York: Oxford University Press, pp. 150-187.

Ul Haq, Mahbub ul, Kaul, Inge, and Grunberg, Isabelle eds. (1996) The Tobin Tax: Coping with Financial Volatility, New York: Oxford University Press

World Bank (1998/99) Global Economic Prospects and the Developing Countries, Washington, D.C.

Zevin, Robert B. (1992) “Are World Financial Markets More Open? If So Why, and With What Effects?" in T. Banuri and J Schor, Financial Openness and National Autonomy, New York: Oxford University Press.

Zysman, John (1983) Governments, Markets and Growth, Ithaca, NY: Cornell University Press. 


\section{TABLE 1. The Growth of Financial Market Transactions}

\section{A) Funds Raised on International Financial Markets as Percentage of World} Exports

\begin{tabular}{|l|l|l|l|l|l|l|l|}
\hline 1950 & 1960 & 1970 & 1975 & 1980 & $\mathbf{1 9 8 5}$ & 1990 & 1997 \\
\hline 0.5 & 1.0 & 1.8 & 4.6 & 5.8 & 13.5 & 10.5 & 23.7 \\
\hline
\end{tabular}

1B) Cross-Border Transactions in Bonds and Equities as Percentage of GDP

\begin{tabular}{|l|l|l|l|l|l|}
\hline & $\mathbf{1 9 8 0}$ & $\mathbf{1 9 8 5}$ & $\mathbf{1 9 9 0}$ & $\mathbf{1 9 9 5}$ & $\mathbf{1 9 9 8}$ \\
\hline United States & 9.0 & 35.1 & 89.0 & 135.5 & 230 \\
\hline Japan & 7.7 & 63.0 & 120.0 & 65.7 & 91 \\
\hline Germany & 7.5 & 33.4 & 57.3 & 168.3 & 334 \\
\hline France & ----- & 21.4 & 53.6 & 178.2 & 415 \\
\hline Italy & 1.1 & 4.0 & 26.6 & 250.9 & 640 \\
\hline Canada & 9.6 & 26.7 & 64.4 & 192.0 & 331 \\
\hline
\end{tabular}

1C) Daily Foreign Exchange Markets Turnover as Percent of Total Central Bank Reserves

\begin{tabular}{|l|l|l|l|l|l|l|l|}
\hline 1977 & 1980 & 1983 & 1986 & 1989 & 1992 & 1995 & 1998 \\
\hline $\mathbf{6 . 9}$ & $\mathbf{2 1 . 3}$ & $\mathbf{3 5 . 0}$ & $\mathbf{5 8 . 8}$ & $\mathbf{8 1 . 7}$ & $\mathbf{9 0 . 0}$ & $\mathbf{9 7 . 7}$ & $\mathbf{9 1 . 7}$ \\
\hline
\end{tabular}

Sources:

Table 1A: OECD International Capital Market Statistics; A. Maddison, Monitoring the World Economy 1820-1992; IMF World Economic Outlook, October 1996; For 1996 and 1997, exports from World Trade Organization Annual Report 1997 and 2000, Table A.3; Funds Raised on Capital Markets, OECD Financial Market Trends, February 1998, Table 1, p. 5.

Table 1B: BIS, 66th Annual Report, p. 98, 67 $67^{\text {th }}$ Annual Report, p. 79, $69^{\text {th }}$ Annual Report, p. 118.

Table 1C: Felix (1998). For 1998, BIS, 71st Annual Report, p. 98, IMF International Financial Statistics Yearbook 1999, p. 17,69.

Note on Table 1A: The 1996 figure for "funds raised on international financial markets" includes only "committed facilities", i.e. excludes "uncommitted facilities," which maintains consistency with the figures for 1950-90. 
Table 2. Real Long-Term Interest Rate in the United States

[10-year Treasury Bond Rate - $\Delta$ GDP Deflator]

\begin{tabular}{|l|l|}
\hline Years & $\begin{array}{l}\text { Real long-term } \\
\text { interest rate }\end{array}$ \\
\hline $1955-59$ & $1.1 \%$ \\
\hline $1960-64$ & 2.7 \\
\hline $1965-69$ & 1.9 \\
\hline $1970-74$ & 1.0 \\
\hline $1975-79$ & 0.8 \\
\hline $1980-84$ & 5.9 \\
\hline $1985-89$ & 5.7 \\
\hline $1990-94$ & 4.4 \\
\hline $1995-99$ & 4.3 \\
\hline
\end{tabular}

Sources: U.S. Federal Reserve Board and Bureau of Economic Analysis 